\title{
PERAN KELOMPOK SWADAYA MASYARAKAT DALAM MEWUJUDKAN PENATAAN KAMPUNG YANG BERKELANJUTAN (STUDI KASUS : KAMPUNG NGEMPLAK, JEBRES, KOTA SURAKARTA)
}

Kusumastuti ${ }^{1}$, Nur Miladan'1, Tendra Istanabi', Lintang Suminar', Galing Yudana', Istijabatul Aliyah'1, Soedwiwahjono', Rizon Pamardhi-Utomo ${ }^{1}$, Rr. Ratri Werdiningtyas ${ }^{1}$, Rama Permana Putra ${ }^{1}$

${ }^{1}$ Program Studi Perencanaan Wilayah dan Kota, Fakultas Teknik, Universitas Sebelas Maret

\begin{abstract}
Abstrak
Sustainable Development Goals (SDG's) memiliki tujuan untuk mengatasi permasalahan kemiskinan, kesenjangan, dan melindungi lingkungan. Konsep Green City atau Kota Hijau merupakan salah satu konsep yang dapat mewujudkan Sustainable Development Goals (SDG's) yang berkaitan dengan isu perkotaan. Kemudian konsep Green City diturunkan menjadi Green Community sebagai topik utama yang akan direalisasikan di Kampung Ngemplak RW 29 melalui pendampingan Kelompok Swadaya Masyarakat (KSM) Kembangkoe agar dapat mewujudkan penataan Kampung Bunga yang berkelanjutan. Terbentuknya Kampung Bunga merupakan tujuan besar yang dalam prosesnya membutuhkan partisipasi bersama masyarakat dengan digerakkan oleh KSM Kembangkoe. Tujuan dari kegiatan ini adalah untuk mengetahui peran Kelompok Swadaya Masyarakat (KSM) Kembangkoe dalam usaha penataan kampung khususnya terbentuknya Kampung Bunga di Kampung Ngemplak RW 29. Metode yang digunakan menggunakan analisis deskriptif kualitatif berdasarkan hasil observasi dan wawancara selama proses pendampingan. Peran KSM Kembangkoe dapat dilihat sebagai fungsi kelembagaan, yaitu memperkuat internal dengan mengarahkan potensi sumberdaya yang dimiliki juga mencari sumberdaya eksternal yang mampu bekerja sama untuk membantu mencapai tujuan didirikannya KSM Kembangkoe.
\end{abstract}

Kata kunci: green community; Kelompok Swadaya Masyarakat (KSM); partisipatif; Sustainable Development Goals (SDG's)

\begin{abstract}
Sustainable Development Goals (SDG's) aim at overcoming the problems of poverty, inequality and protecting the environment. The concept of Green City is one of the concepts that can realize Sustainable Development Goals (SDG's) related to urban issues. Then the concept of Green City was focused on Green community as the main topic to be implemented in Kampung Ngemplak RW 29 with the Kembangkoe Voluntary Group (KSM) as the facilitator to create a sustainable Kampung Bunga or the village of flower. of the development of Kampung Bunga is the major that requires community's participation assisted by KSM Kembangkoe. The paper aims atinvestigating the role of KSM Kembangkoe in managing the efforts, especially related to the formation of Kampung Bunga in Kampung Ngemplak RW 29. The method used is a qualitative description based on observations during the mentoring process. The role of KSM Kembangkoe can be seen as an institutional function that is to strengthen the community by managing the potential of local resources as well as working with external resources to work together helping to achieve the goals of the establisment of KSM Kembangkoe.
\end{abstract}

Keywords: Community Voluntary Contribution Group; green community; partisipation; Sustainable Development Goals (SDG's)

\section{PENDAHULUAN}

Orientasi pembangunan saat ini sudah bergeser pada pembangunan yang tidak hanya mementingkan generasi saat ini namun bagaimana generasi yang akan datang juga tetap mampu bertahan dan berkembang. Kata kunci keberlanjutan atau sustainable kemudian dilekatkan pada usaha pembangunan. Sustainable Development Goals (SDGs) selanjutnya muncul dan menjadi arus utama setiap orientasi pembangunan. Sustainable Development Goals memiliki 17 aspek yang berasal dari berbagai dimensi (United Nation, 2015). Secara umum, berbagai dimensi tersebut mewakili irisan dari dimensi sosial, lingkungan, dan ekonomi. 
Sustainable city atau kota berkelanjutan merupakan turunan dari konsep makro pembangunan berkelanjutan yang khusus menangani isu-isu pembangunan kota. Konsep Green City atau Kota Hijau merupakan usaha menerjemahkan konsep kota berkelanjutan karena pembangunan kota harus bisa selaras dan ramah dengan lingkungan. Kota hijau berusaha untuk mewujudkan tatanan kota berkelanjutan dengan menyeimbangkan antara kebutuhan pembangunan ekonomi, perkembangan sosial, dan eksistensi lingkungan (Budihardjo \& Sujarto, 2005). Kota hijau memiliki delapan konsep pendukung, yaitu green planning, green community, green open space, green building, green energy, green transportation, green water, dan green waste.

Green community atau komunitas hijau merupakan satu dari delapan konsep pendukung terwujudnya kota hijau. Green community menekankan pada pelibatan komunitas masyarakat sebagai motor penggerak bagi terwujudnya kota hijau tersebut (Suyanto, Soetarto, Sumardjo, \& Hardjomidjojo, 2015). Komunitas masyarakat saat ini merupakan subyek dan obyek utama pembangunan sehingga pelibatan masyarakat menjadi keharusan dalam pembangunan. Pelibatan masyarakat juga mampu mengarahkan setiap program menjadi lebih tepat sasaran. Selain itu, keberadaan kelembagaan dan institusi di masyarakat dapat semakin memudahkan dalam mengorganisasi masyarakat karena komunitas masyarakat yang sudah melembaga memiliki pergerakan yang lebih teratur dan tertata.

Dalam mewujudkan green community dibutuhkan usaha terjun langsung dan berinteraksi pada masyarakat dengan pendekatan partisipatif. Pendekatan partisipatif adalah proses adanya keikutsertaan masyarakat dalam proses identifikasi potensi dan masalah, pemilihan alternatif solusi dan penanganan masalah secara kolektif (Adi, 2008). Interaksi tersebut bertujuan untuk memahami potensi dan masalah secara lebih mendalam. Hal tersebut juga merupakan bentuk implementasi praksis dari mewujudkan konsep besar kota hijau dengan langkah kecil dari komunitas kecil masyarakat. Maka dari itu, dibutuhkan kerjasama dan partisipasi langsung dengan masyarakat.

Potensi keberadaan green community dimiliki oleh komunitas masyarakat di Kampung Ngemplak RW 29 Kelurahan Mojosongo, Kota Surakarta. Kampung tersebut memiliki Kelompok Swadaya Masyarakat (KSM) Kembangkoe yang mendorong terbentuknya gagasan pembentukan Kampung Bunga. Kampung Bunga adalah gagasan dari warga Kampung Ngemplak RW 29 untuk menjadikan kampungnya sebagai produsen bunga mawar, melati, dan matahari. Motivasi ini muncul karena terinspirasi dari keberadaan Kampung Sayur yang berada di sebelah Kampung Ngemplak. Selain itu, Kampung tersebut juga sudah memiliki penggerak dan kelembagaan yang mampu mengelola, membangun jaringan untuk mengembangkan gagasan bagi terwujudnya cita-cita kampung bunga tersebut.

Walaupun Kampung Ngemplak RW 29 sudah memiliki potensi bagi pengembangan Kampung Bunga, namun masih memiliki sejumlah kendala. Kendala yang dimiliki, yaitu kendala kekurangan dana, keterbatasan jejaring, dan keterbatasan kapasitas. Masyarakat di kampung ini secara umum merupakan komunitas masyarakat kampung kota yang awam terhadap kegiatan perkebunan sehingga secara teknis masyarakat belum memiliki kapasitas dan pengetahuan untuk membudidayakan bunga mawar, melati dan matahari.

Berdasarkan kondisi tersebut, tim dosen dari Grup Riset Sustainable Development and Design dari Program Studi Perencanaan Wilayah dan Kota UNS melakukan program pengabdian dengan tujuan untuk memfasilitasi terbentuknya dan berjalannya Kampung Bunga di Kampung Ngemplak RW 29 Mojosongo. Keberadaan Kampung Bunga tersebut nantinya diharapkan mampu memberikan alternatif pemasukan ekonomi sebagai manfaat pertama. Alternatif pemasukan ekonomi dapat menjadi bentuk ketangguhan ekonomi lokal (economic resilience) masyarakat. Kedua, meningkatkan soliditas kemasyarakatan. Komunitas masyarakat yang memiliki visi dan cita-sita sama kemudian berusaha bersama akan menghasilkan modal sosial yang lebih kuat. Ketiga, secara estetis mampu meningkatkan citra kawasan. Kampung Ngemplak akan menjadi kampung yang secara estetis, berbeda dengan kampung lainnya karena dipenuhi dengan bunga. Hal ini juga menunjukan kreativitas warga masyarakat dalam mengelola potensi kampung. Program pengabdian tersebut selanjutnya penulis terjemahkan dalam artikel ilmiah ini. 


\section{KAJIAN PUSTAKA}

\subsection{SUSTAINABLE DEVELOPMENT GOALS (SDGS)}

Sustainable Development Goals (SDGs) merupakan sebuah tema besar pembangunan dunia yang digunakan sebagai arus utama arah pembangunan dari berbagai sektor (UN, 2015). Sustainable Development Goals (SDGs) merupakan kelanjutan dari Milenium Development Goals (MDGs) yang dideklarasikan tahun 2000 dan berlaku sampai 2015 yang terdiri dari delapan tujuan (Kementerian PPN/Bappenas, n.d.; SDGs, n.d.). Sementara itu, SDGs berlaku 2016 sampai dengan 2020 dengan 17 tujuan. Menurut UN, (2019), tujuh belas tujuan tersebut, yaitu: (1) Tanpa kemiskinan, (2) Tanpa kelaparan, (3) Kehidupan sehat dan sejahtera, (4) Pendidikan berkualitas, (5) Kesetaraan gender, (6) Air bersih dan sanitasi layak, (7) Energi bersih dan terjangkau, (8) Pekerjaan layak dan pertumbuhan ekonomi, (9) Industri, inovasi dan infrastruktur, (10) Berkurangnya kesenjangan, (11) Kota dan komunitas berkelanjutan, (12) Konsumsi dan produksi yang bertanggung jawab, (13) Penanganan perubahan iklim, (14) Ekosistem laut, (15) Ekosistem darat, (16) Perdamaian, keadilan dan kelembagaan yang tangguh, dan (17) Kemitraan untuk mencapai tujuan.

Konsep pembangunan berkelanjutan disederhanakan ke dalam konsep sehingga terjadi keseimbangan antara ekonomi, sosial, dan lingkungan dalam setiap pembangunan. Pembangunan berkelanjutan adalah titik tengah atau irisan dari ketiganya karena integrasi ketiga elemen tersebut bertujuan untuk menghasilkan pembangunan yang tidak hanya berorientasi pada generasi saat ini tetapi juga generasi yang akan datang. Selain itu, pembangunan berkelanjutan juga merupakan irisan dari dimensi sosial, lingkungan, dan ekonomi.

Indonesia merupakan salah satu negara yang telah menyepakati penerapan tujuan Sustainable Development Goals (SDGs) yang diterjemahkan dengan istilah pembangunan berkelanjutan. Indonesia berkomitmen untuk menyukseskan pelaksanaan pembangunan berkelanjutan melalui berbagai kegiatan dan telah mengambil langkah-langkah strategis (Badan Pusat Statistik, 2016). Pembangunan berkelanjutan selanjutnya digunakan dan diadopsi dalam berbagai wacana program pembangunan oleh berbagai elemen. Birokrat, akademisi, swasta merupakan bagian elemen tersebut yang secara nyata bersinggungan dengan wacana pembangunan berkelanjutan.

\subsection{PENDEKATAN PARTISIPATIF DAN GREEN COMMUNITY}

Berdasarkan uraian yang dijelaskan dalam paragraf sebelumnya, pembangunan berkelanjutan memuat 17 tujuan yang melingkupi berbagai sektor. Pada tujuan ke-11, pembangunan berkelanjutan menyoroti pada isu perkotaan dan permukiman dengan tujuan, yaitu membangun kota dan permukiman inklusif, aman, tahan lama, dan berkelanjutan. Tujuan ke-11 merupakan bentuk perhatian terhadap isu lingkungan permukiman khususnya kota yang inklusif atau dapat dirasakan dan dinikmati oleh berbagai kalangan. Setiap fasilitas lingkungan permukiman yang layak harus mampu dirasakan sampai pada level terendah (United Nation, 2015).

Selanjutnya, apabila dilihat lebih mendalam tujuan ke-11 ini dijabarkan dalam tujuh target. Pada tulisan ini penulis menggarisbawahi poin penting dalam target tersebut, yaitu perencanaan dan pengelolaan permukiman yang partisipatoris dan penyediaan akses universal terhadap ruang-ruang publik yang aman, inklusif dan mudah diakses, dan hijau. Jadi pendekatan partisipatif menjadi sangat penting terutama dalam usaha penyediaan ruang-ruang publik. Salah satu penekanan ruang publik tersebut adalah ruang publik hijau atau ruang terbuka hijau. Apabila dikaitkan lagi, ruang terbuka hijau merupakan bagian juga dari konsep Green City atau Kota Hijau karena konsep ini menerjemahkan konsep kota berkelanjutan yang pembangunan kotanya harus bisa selaras dan ramah dengan lingkungan.

Kota hijau memiliki delapan konsep pendukung, yaitu green planning, green community, green open space, green building, green energy, green transportation, green water, dan green waste (Budihardjo \& Sujarto, 2005). Berdasarkan delapan konsep pendukung Kota Hijau tersebut dapat ditemukan keterhubungannya melalui konsep green community. Konsep green community menjadi benang merah dari target perencanaan dan pengelolaan pemukiman yang partisipatoris dan penyediaan akses universal terhadap ruang-ruang publik yang aman, inklusif dan mudah diakses, dan hijau. 


\subsection{KOMUNITAS DAN KAMPUNG KOTA}

Menurut Kamus Tata Ruang (1997), komunitas adalah suatu kelompok dengan ciri dan karakteristik tersendiri, memiliki kesatuan organisasi tertentu yang hidup dan berinteraksi dalam suatu wilayah tertentu. Nasdian (2014) selanjutnya menjelaskan komunitas merupakan unit atau kesatuan sosial yang terorganisasi dalam kelompok tertentu. Kelompokkelompok tersebut selanjutnya akan berkembang dan memiliki kepentingan yang bersifat kolektif baik bersifat fungsional maupun teritorial. Perspektif sosiologis menempatkan istilah komunitas (community) sebagai warga setempat dan membedakannya dengan istilah masyarakat luas (society). Maka, istilah komunitas ini ditujukan pada kumpulan masyarakat lokal yang lebih kecil yang memiliki keterikatan secara sosial. Keterikatan ini dapat berupa teritori, seperti desa, dusun, kampung dan lainnya atau berupa kesamaan tujuan, seperti komunitas hobi, komunitas profesi dan lainnya. Intinya, sebuah komunitas pasti memiliki nilai tertentu yang apabila semakin lama komunitas itu ada, setiap anggotanya akan semakin memiliki rasa saling membutuhkan, senasib, dan sepenanggungan.

Salah satu bentuk komunitas yang berbasis pada teritori adalah komunitas kampung. Komunitas kampung ini tidak hanya berada di perdesaan tetapi juga di kota. Perkampungan di kota kemudian diistilahkan dengan kampung kota. Kampung kota merupakan kumpulan permukiman yang berada di perkotaan namun masih sangat kental dengan ciri khas masyarakat kampung. Masyarakat kampung memiliki keunikan dan kekhasan, yaitu kekuatan dan kedekatan sosialnya yang menunjukkan sejarah panjang perjuangan dan perasaan senasib antar warganya. Setiap kampung mampu menunjukkan wajah yang berbeda dengan kampung lainnya. Wajah tersebut menggambarkan akumulasi adat istiadat dan budaya masyarakat setempat yang otentik. Jadi, kampung kota tidak hanya sekedar fisik, tetapi sebuah sistem sosial yang kompleks dan dinamis (Setiawan, 2010).

Kampung dalam paradigma masyarakat secara umum identik dengan keterbelakangan dan ketidakmajuan. Secara fisik terlihat pertumbuhan yang acak dan terkesan tidak tertata serta dalam banyak kasus merupakan permukiman padat dengan penduduk menengah ke bawah secara ekonomi. Namun, walaupun dipenuhi dengan keterbatasan Kampung Kota menjadi kawasan permukiman yang memiliki identitas kuat yang terbentuk dari aktivitas warganya (Sumintarsih \& Andrianto, 2014). Kampung merupakan cerminan integrasi mengarah pada kompleksitas Kampung Kota dengan keanekaragaman aktivitas keseharian masyarakatnya. Permukiman kampung awalnya berakar dari integrasi sektor formal dan informal yang terdapat keterkaitan aspek sosial, ekonomi dan fisik yang menjadi bagian dari kota (Hamidah, Rijanta, Setiawan, \& Marfai, 2016). Keterbatasan ruang menjadikan semua ruang harus dapat dioptimalkan pemanfaatannya sehingga memberi dampak yang lebih baik bagi kehidupan dan menjamin keberlanjutan. Menurut Cahyo dalam Makhmud (2017), ruang-ruang sirkulasi yang kecil membentuk perilaku yang spesifik bagi masyarakat penghuni.

\section{METODE}

Tulisan ini diangkat dengan pendekatan kualitatif terhadap sebuah isu permasalahan. Peneliti melakukan eksplorasi terhadap obyek, yaitu Kampung Ngemplak untuk kemudian dilakukan analisis terhadap kondisi saat ini. Metode demikian lebih mengarah pada penelitian bersifat kualitatif. Penelitan kualitatif melihat obyek penelitian sebagai sebuah kesatuan yang dinamis. Maka, dibutuhkan konstruksi pemikiran dan interpretasi mendalam dalam melihat gejala-gejala yang ditampilkan oleh obyek penelitian. Metode kualitatif mampu membahas sebuah obyek penelitian secara mendalam. Kedalaman penelitian diwujudkan dalam upaya eksplorasi terhadap obyek penelitian. Sementara itu, penelitian kualitatif juga bersifat dinamis karena interaksi antara peneliti dan sumber data tidak terikat oleh nilai-nilai tertentu. Sebelum memandang obyek penelitian, peneliti memiliki sudut pandang dan latar belakang tertentu sebagai background knowledge (Sugiyono, 2011).

Teknik analisis yang digunakan selanjutnya menggunakan analisis deskriptif. Menurut Sugiyono (2011), analisis deskriptif dilakukan dengan usaha menggambarkan suatu keadaan objektif sebuah peristiwa tertentu dengan berdasarkan fakta untuk menghasilkan kesimpulan yang bersifat umum.

Sementara itu, metode pengumpulan data dilakukan dengan kegiatan observasi dan wawancara mendalam terhadap obyek. Observasi dilakukan untuk menangkap gejala yang terlihat secara visual yang selanjutnya dilakukan verifikasi dengan wawancara terhadap beberapa orang yang dinilai memiliki kemampuan untuk menjelaskan. Maka dari itu, wawancara dilakukan dengan purposive sampling. 


\section{HASIL DAN PEMBAHASAN}

\subsection{KELOMPOK SWADAYA MASYARAKAT (KSM) KEMBANGKOE SEBAGAI WUJUD GREEN COMMUNITY}

Kampung Ngemplak berjarak kurang lebih 7 Kilometer dari Kampus Universitas Sebelas Maret. Warga Kampung Ngemplak mendirikan Kelompok Swadaya Masyarakat (KSM) berawal dari kesadaran bersama masyarakat terhadap pengembangan potensi lokal. Adanya teori sosial ini merupakan bentuk dari keberadaan modal sosial yang dimiliki warga Kampung Ngemplak. Ide pengembangan potensi tersebut kemudian dibicarakan dan dikerjakan bersama secara kolektif dengan memanfaatkan sumber daya yang dimiliki. Kolektivitas ini selanjutnya pasti akan menumbuhkan partisipasi masyarakat lainnya. Partisipasi masyarakat ini dikelola oleh beberapa tokoh dan disalurkan serta diatur sedemikian rupa melalui wadah kelembagaan sehingga kegiatan dapat dilaksanakan secara terorganisir dan teratur.

KSM Kembangkoe menjadi penggerak utama terwujudnya keinginan warga masyarakat. Adanya wadah lembaga khusus juga memungkinkan tujuan bersama dapat berjalan lebih fokus. Fokus ini penting untuk mampu menyusun tujuan dan langkahlangkah kongkret yang harus dilakukan. Fungsi kelembagaan selain memperkuat dari dalam juga berusaha mencari sumberdaya dari luar yang mampu bekerja sama untuk membantu mencapai tujuan didirikannya KSM Kembangkoe. Keberadaan KSM Kembangkoe mampu menghasilkan kerjasama eksternal dengan pihak di luar Kampung Ngemplak RW 29. Kerjasama ini salah satunya terjalin dengan akademisi dari Universitas Sebelas Maret Surakarta. Kerjasama ini selanjutnya menjadi bentuk pendampingan terhadap KSM Kembangkoe untuk mampu mengembangkan potensi dan mengatasi masalah yang dimiliki.

Keberadaan KSM Kembangkoe ini juga merupakan bentuk dari implementasi green community. KSM Kembangkoe menjadi wadah bagi usaha penyediaan ruang terbuka hijau dan kegiatan perkebunan, khususnya bunga di lingkungan perkotaan. Kegiatan KSM Kembangkoe ini mampu menumbuhkan kesadaran komunitas terhadap pentingnya pengelolaan potensi lokal dan terlebih berkaitan dengan potensi pengelolaan ruang terbuka hijau yang mampu memberikan dampak positif bagi lingkungan permukiman.

\subsection{PENDAMPINGAN DAN PENGEMBANGAN POTENSI}

Pendampingan menjadi sangat penting karena komunitas lokal memiliki keterbatasan terutama akses terhadap keilmuan dan pendanaan. Pendampingan dilakukan oleh lembaga yang dinilai mampu secara keilmuan mengarahkan pengembangan potensi dan pemecahan masalah. Berdasarkan hasil pendampingan, dapat terjaring beberapa kendala berupa kekurangan dana, keterbatasan jejaring, dan keterbatasan kapasitas. Berdasarkan kendala tersebut, selanjutnya dilakukan proses partisipatif sehingga menghasilkan beberapa solusi. Solusi pertama, yaitu dengan menjadikan masyarakat Kampung Ngemplak RW 29 sebagai produsen unggulan budidaya bunga melati, bungi mawar, dan bunga matahari. Solusi pertama lebih ditujukan untuk perputaran ekonomi sehingga dapat diketahui adanya progres signifikan dari adanya produksi budidaya bunga di Kampung Ngemplak RW 29. Solusi kedua lebih difokuskan untuk peningkatan kapasitas dengan diadakannya pelatihan budidaya bunga melati, bunga mawar dan bunga matahari. Pelatihan ini dilaksanakan dengan mendatangkan ahli yang dengan hal terkait, dan diharapkan dapat memberikan pengetahuan baru yang bisa dijadikan sebagai dasar adanya budidaya bunga oleh masyarakat Kampung Ngemplak RW 29. Solusi ketiga, yaitu dengan melakukan pendampingan dalam upaya membangun lahan pembibitan. Selain itu, juga dilakukan penambahan sarana yang dapat mempercepat upaya budidaya bunga. Berdasarkan ketiga solusi tersebut diharapkan masyarakat Kampung Ngemplak RW 29 dapat mengembangkan kegiatannya.

Solusi-solusi tersebut selanjutnya dijabarkan dalam beberapa tahapan pelaksanaan. Tahap pertama dimulai dengan tahap persiapan. Tahap persiapan dilakukan dengan membangun mitra dan membuat kesepakatan mitra kesepakatan awal. Hal tersebut dilakukan agar program berjalan secara sinergis dan tidak terjadi kesalahpahaman. Tahap persiapan ini melibatkan tim pengabdian serta tokoh masyarakat RW 29, Kelurahan Mojosongo. Pada tahap selanjutnya, yaitu tahap pelaksanaan dengan melakukan penyusunan rencana bersama dengan masyarakat merupakan bentuk proses perencanaan partisipatif. Proses ini melibatkan masyarakat RW 29, Kelurahan Mojosongo untuk mengenali potensi masalah, mampu memilih alternatif keputusan, dan bersama-sama menjalankan keputusan bersama untuk penataan kampung bunga. Pada tahap ini, masyarakat RW 29, Kelurahan Mojosongo, bergotong-royong dalam penyediaan dan perancangan lahan pembibitan, penyediaan sarana/ 
peralatan/bahan pendukung kampung bunga, seperti pot, media tanam, dan lain-lain, serta pembentukan kelompok kerja pembibitan.

Dalam penyediaan dan perancangan lahan pembibitan, masyarakat RW 29 Kelurahan Mojosongo membuat lahan sebagai media dasar untuk pembibitan seluas $21 \mathrm{~m}^{2}$ yang terbuat dari susunan bambu dan diberikan pelindung berupa paranet. Kemudian, masyarakat RW 29 Kelurahan Mojosongo juga menambahkan titik-titik pengairan yang ada di Taman May Virida, RW 29, Kelurahan Mojosongo untuk mempermudah saat penyiraman tanaman. Terakhir, pada tahap evaluasi, yaitu melakukan pengamatan terhadap program-program yang sudah dilaksanakan. Berikut merupakan diagram alir proses pelaksanaan pendampingan masyarakat RW 29 Kelurahan Mojosongo yang dapat dilihat pada Gambar 1.
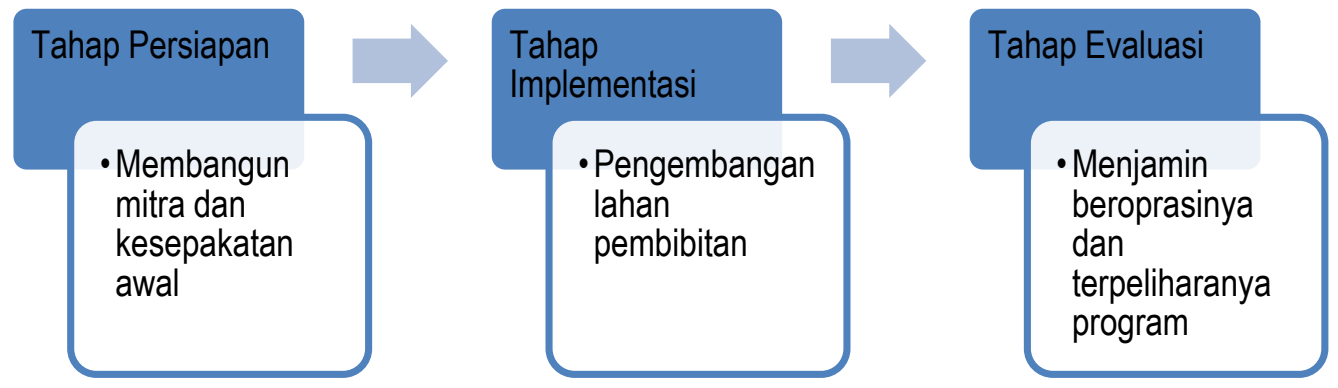

\section{Gambar 1. Proses Pelaksanaan Pendampingan}

\subsection{PARTISIPASI MASYARAKAT KAMPUNG NGEMPLAK RW 29}

Partisipsi masyarakat Kampung Ngemplak sangat tinggi berkaitan dengan proses terwujudnya Kampung Bunga. Pada kegiatan pendampingan, masyarakat Kampung RW 29 bekerja secara gotong-royong terutama dalam tahapan pengembangan lahan pembibitan. Partisipasi masyarakat pertama dapat dilihat dari terlaksananya program perbaikan dan pavingisasi di Taman May Virida yang berlokasi di Kampung Ngemplak RW 29. Perbaikan ini telah dilakukan secara bertahap oleh masyarakat RW 29 pada tanggal 16 Agustus 2020. Selain untuk menambah kesan keindahan, program ini juga dapat menambah kenyamanan taman khususnya untuk mendukung program utama, yaitu pembibitan bunga matahari, bunga mawar, dan bunga melati.

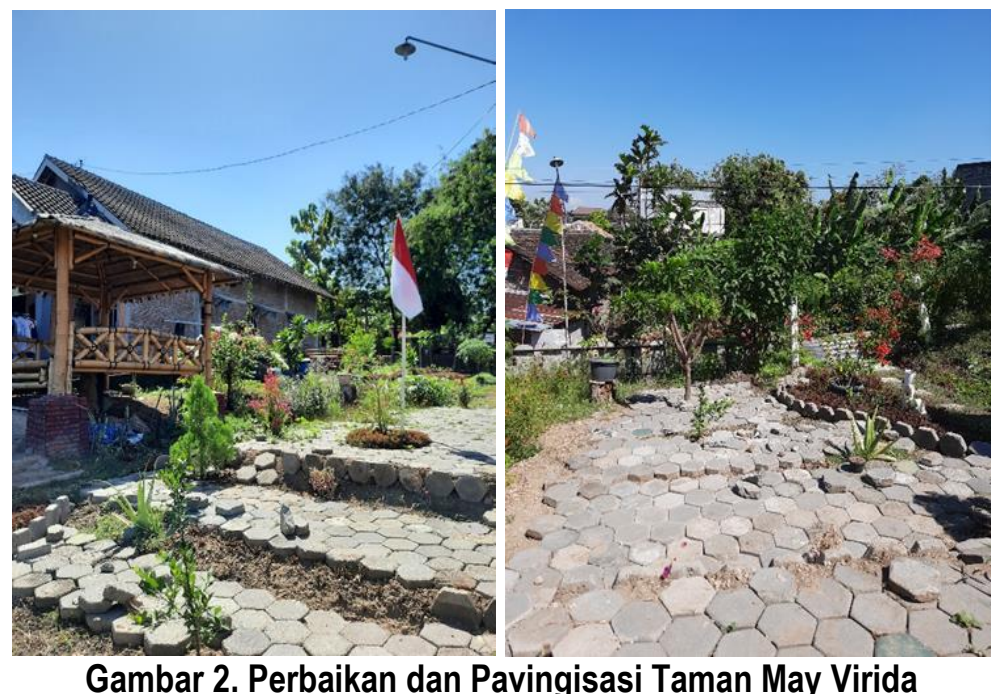

Partisipasi selanjutnya dapat dilihat pada kegiatan penambahan titik pengairan yang direalisasikan dengan penambahan kran yang awalnya hanya tersedia satu menjadi tiga titik. Penambahan 2 titik pengairan ini dilakukan secara bergotong-royong oleh warga RW 29, Kelurahan Mojosongo pada tanggal 23 Agustus 2020. Tujuan dari penambahan titik pengairan yang 
tersebar di taman ini adalah agar dapat mempermudah pengairan taman khususnya saat pembibitan bunga melati, bunga matahari,dan bunga mawar.
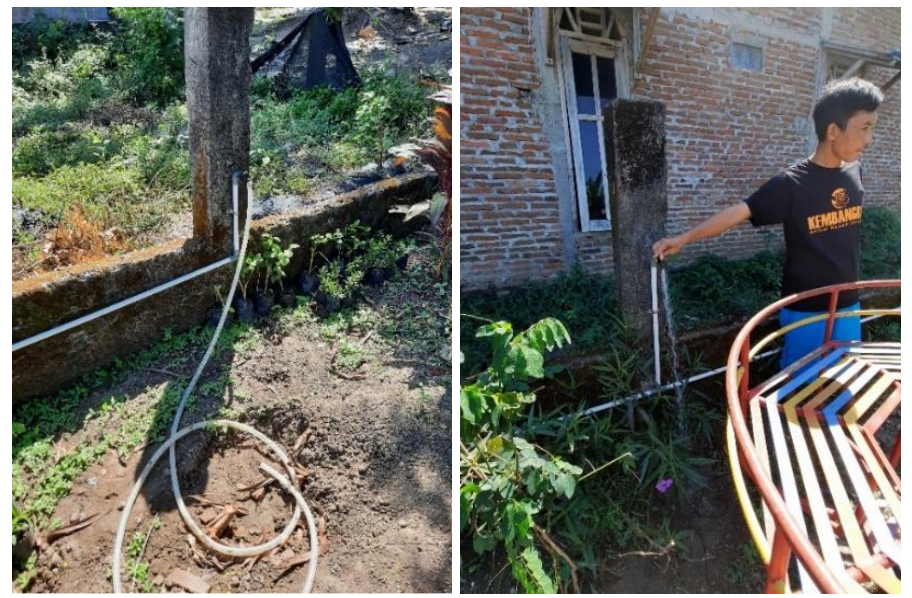

\section{Gambar 3. Penambahan 2 Titik Pengairan}

Faktor pendukung yang dihadapi pada program kerja ini adalah pihak masyarakat dan Ketua RW antusias dalam bergotong-royong melaksanakan program kerja ini. Sedangkan, faktor penghambat yang dihadapi, yaitu keterlambatan masyarakat pada hari pelaksanaan program ini. Selain itu, pembuatan lahan untuk pembibitan juga diimplementasikan. Pembuatan lahan untuk pembibitan ini dilakukan secara gotong-royong oleh warga RW 29, Kelurahan Mojosongo. Pembuatan lahan ini berjalan sejak tanggal 27 Agustus 2020, dan sampai saat ini masih proses finalisasi untuk disiapkan sebagai media yang dikhususkan untuk tahap pembibitan bunga. Lahan yang diperlukan untuk pembibitan ini memiliki panjang kurang lebih 7 meter dan lebar kurang lebih 3 meter dengan luas $21 \mathrm{~m}^{2}$. Lahan untuk pembibitan ini disusun dengan bambu sebagai tiang penguat dan paranet sebagai pelindung tanaman, khususnya saat pembibitan atau pembenihan tanaman dan juga mampu menjaga dari paparan langsung terik matahari dan curah hujan yang dapat merusak tanaman.

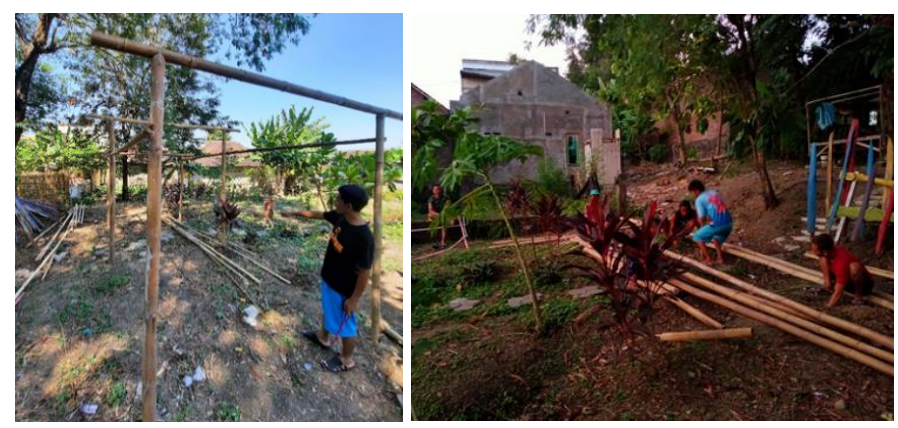

Gambar 4. Pembuatan Lahan untuk Pembibitan

\section{KESIMPULAN}

Orientasi pembangunan saat ini sudah bergeser pada pembangunan yang tidak hanya mementingkan generasi saat ini, namun bagaimana generasi yang akan datang juga tetap mampu bertahan dan berkembang. Kata kunci keberlanjutan atau sustainable kemudian dilekatkan pada usaha pembangunan. Konsep Green City atau Kota Hijau merupakan usaha menerjemahkan konsep kota berkelanjutan dengan mengimplementasikan pembangunan kota yang harus bisa selaras dan ramah dengan lingkungan. Green community atau komunitas hijau merupakan satu dari delapan konsep pendukung terwujudnya kota hijau. Green community menekankan pada pelibatan komunitas masyarakat sebagai motor penggerak bagi terwujudnya kota hijau tersebut. Keberadaan KSM Kembagkoe ini juga merupakan bentuk dari implementasi green community. KSM Kembangkoe menjadi wadah bagi usaha penyediaan ruang terbuka hijau dan kegiatan perkebunan, khususnya bunga di lingkungan perkotaan Kampung Ngemplak RW 29. KSM Kembangkoe menjadi penggerak utama 
terwujudnya keinginan warga masyarakat. Adanya wadah lembaga khusus juga memungkinkan tujuan bersama dapat berjalan lebih fokus. Fokus ini penting untuk mampu menyusun tujuan dan langkah-langkah kongkret yang harus dilakukan. Fungsi kelembagaan selain memperkuat internal, juga berusaha mencari sumberdaya eksternal yang mampu bekerja sama untuk membantu mencapai tujuan didirikannya KSM Kembangkoe.

Namun demikian, potensi tersebut sepenuhnya muncul dari lokalitas sehingga memiliki beberapa kendala berupa kekurangan dana, keterbatasan jejaring, dan keterbatasan kapasitas. Adanya kendala tersebut, dibutuhkan pendampingan dari luar dalam rangka untuk mengatasi segala kendala secara partisipatif sehingga menghasilkan solusi bersama. Proses partisipatif tersebut merupakan bentuk dari pengembangan komunitas sehingga seluruh eleman komunitas masyarakat di Kampung Ngemplak RW 29 dapat terlibat dan merasa memiliki tujuan bersama. Adanya kegiatan pendampingan tersebut, juga dapat dilihat bahwa partisipsi masyarakat Kampung Ngemplak RW 29 sangat tinggi berkaitan dengan proses terwujudnya Kampung Bunga. Pada kegiatan pendampingan, masyarakat Kampung Ngempllak RW 29 bekerja secara gotong-royong terutama dalam tahapan pengembangan lahan pembibitan.

\section{UCAPAN TERIMAKASIH}

Ucapan terimakasih kepada Lembaga Penelitian dan Pengabdian Kepada Masyarakat (LPPM), Universitas Sebelas Maret yang telah memberikan dukungan teknis dan pendanaan sehingga program pengabdiaan kepada masyarakat ini dapat terlaksana. Ucapan terimakasih juga disampaikan kepada Kelompok Swadaya Masyarakat (KSM) Kembangkoe dan seluruh masyarakat RW 29 yang telah bekerja sama dengan baik dalam pelaksanaan kegiatan ini.

\section{DAFTAR PUSTAKA}

Adi, I. R. (2008). Intervensi Komunitas: Pengembangan Masyarakat sebagai Upaya Pemberdayaan Masyarakat. Jakarta: Rajawali Press.

Badan Pusat Statistik. (2016). Potret Awal Tujuan Pembangunan Berkelanjutan (Sustainable Development Goals) di Indonesia. Jakarta: Badan Pusat Statistik. Retrieved from https://filantropi.or.id/pubs/uploads/files/3 BPS Potret Awal TPB di Indonesia.pdf

Budihardjo, E., \& Sujarto, D. (2005). Kota Berkelanjutan. Bandung: PT. Alumni.

Ditjen Cipta Karya Depertemen Pekerjaan Umum, \& Ikatan Ahli Perencanaan. (1997). Kamus Tata Ruang. Jakarta: Direktorat Jenderal Cipta Karya, Departemen Pekerjaan Umum.

Hamidah, N., Rijanta, R., Setiawan, B., \& Marfai, M. A. (2016). Kampung sebagai Model Permukiman Berkelanjutan di Indonesia. Jurnal Inersia, 12(2), 114-124. https://doi.org/10.21831/inersia.v12i2.12586

Kementerian PPN/Bappenas. (n.d.). Sekilas SDGs. Retrieved from http://sdgs.bappenas.go.id/sekilas-sdgs/

Makhmud, D. F., Nurhasanah, F., Utami, I. U., Khansa, S., Radnawati, D., \& Syahadat, R. M. (2017). Mewujudkan Kampung Bandan Sebagai Kampung Kota Berkelanjutan Menggunakan Pendekatan Asian New Urbanism. Jurnal Arsitektur, Bangunan, Dan Lingkungan, 6(3), 91-100. Retrieved from https://www.neliti.com/id/publications/185920/mewujudkan-kampung-bandan-sebagaikampung-kota-berkelanjutan-menggunakan-pendeka\#cite

Nasdian, F. T. (2014). Pengembangan Masyarakat. Jakarta: Yayasan Pustaka Obor Indonesia.

SDGs. (n.d.). Apa itu SDGs. Retrieved from www.sdg2030indonesia website: https://www.sdg2030indonesia.org/page/8-apa-itu

Setiawan, B. (2010). Kampung Kota Dan Kota Kampung-Potret Tujuh Kampung di Kota Jogja. Yogyakarta: Pusat Studi Lingkungan Hidup UGM.

Sugiyono. (2011). Metode Penelitian Kuantitatif Kualitatif dan R\&D. Bandung: Alphabeta.

Sumintarsih, \& Andrianto, A. (2014). Dinamika Kampung Kota: Prawirotaman dalam Perspektif Sejarah dan Budaya. Yogyakarta: Balai Pelestarian Nilai Budaya (BPNB) DI Yogyakarta.

Suyanto, E., Soetarto, E., Sumardjo, \& Hardjomidjojo, H. (2015). Model Kebijakan Pengelolaan Sampah Berbasis Partisipasi "Green Community" Mendukung Kota Hijau. MIMBAR Jurnal Sosial Dan Pembangunan, 31(1), 143-152. https://doi.org/10.29313/mimbar.v31i1.1295

United Nation. (2015). Transforming our world: the 2030 Agenda for Sustainable Development. In General Assembly. Retrieved from https://www.un.org/ga/search/view_doc.asp?symbol=A/RES/70/1\&Lang=E

United Nation. (2019). The Sustainable Development Goals Report. New York. Retrieved from https://unstats.un.org/sdgs/report/2019/TheSustainable-Development-Goals-Report-2019.pdf 